\title{
Glucose utilization by components of the mouse conceptus during early embryogenesis
}

\author{
R. G. Wales*, K. L. Martin and H. J. Leese \\ Department of Biology, University of York, Heslington, York YO1 5DD, UK
}

\begin{abstract}
Mouse conceptuses were collected from female mice between day 6.5 and day 9.5 of pregnancy, dissected into their component parts and incubated for $2.5 \mathrm{~h}$ at $37^{\circ} \mathrm{C}$ in droplets of Hepes-buffered medium containing $I$ or $5 \mathrm{mmol}$ glucose $1^{-1}$ supplemented with $0.33 \mathrm{mmol}$ pyruvate $1^{-1}$ plus either 1 or $5 \mathrm{mmol}(\mathrm{DL})$ lactate $1^{-1}$ under oil. Glucose disappearance and lactate appearance were measured enzymatically at the end of incubation. High glucose concentration doubled utilization of this substrate per microgram of embryonic protein, but the change in lactate concentration had no effect on glucose turnover. Over the whole period of development studied, tissue from the ectoplacental cone exhibited the lowest rate of glucose turnover of all tissues isolated. At day 8.5, there was little difference between yolk sac and embryonic tissues, but by day 9.5, the yolk sac had a higher rate of utilization of glucose than did embryonic tissues. By this time, the embryonic tissues had started to show some metabolic differentiation, with head and visceral tissue exhibiting $20 \%$ higher turnover of glucose than that of body tissue. Overall, the rate of glucose utilization fell as development progressed and the estimate of the relative rate of glucose utilization on day 9.5 was half the value on day 6.5 .
\end{abstract}

\section{Introduction}

All evidence thus far available indicates that glucose is the major energy source for the vertebrate conceptus during initial differentiation and development. Spratt (1958), for example, reported that glucose is the most effective substrate to support differentiation of chick embryos and it was shown that this substrate is important for development of rat conceptuses in vitro (Gunberg, 1976; Cockroft, 1979). Glucose utilization is high in early postimplantation embryos but falls dramatically with development (Tanimura and Shepard, 1970).

As early as 1967, Papaconstantenou recognized that developing cells can regulate the activity of specific pathways of carbohydrate metabolism during specific stages of differentiation, a control that may be mediated through feedback and allosteric effects, as well as differential reading of the genome. Although rat postimplantation embryos rely heavily on anaerobic glycolysis for their energy requirements (Tanimura and Shepard, 1970), Shepard et al. (1970) reported a progressive reduction in the proportion of glucose converted to lactate by rat embryos as development progresses, a change confirmed by Ellington (1987). Furthermore, in experiments monitoring the contractability of isolated rat embryo hearts, Cox and Gunberg $(1972 a, b)$ deduced that, in this organ, there is a move away from glycolysis to other pathways as development progresses.

Although these studies have provided some insight into energy utilization during organogenesis, no attempt has been

*Present address: School of Veterinary Studies, Murdoch University, Murdoch, WA 6150, Australia.

Received 16 November 1994. made to follow systematically the energy metabolism of specific components of the embryo during the period when development and commitment lead to the formation of extraembryonic membranes and embryonic organs and tissues. The only study to date in the mouse is that of Clough and Whittingham (1983) using amnion-intact embryos. The present project was undertaken to measure the turnover of glucose by the extraembryonic membranes and tissues of developing mouse conceptuses over the period of organogenesis from day 6.5 to day 9.5 of gestation and to gauge the effects of changes in substrate concentration.

\section{Materials and Methods}

Animals and treatments

$\mathrm{F}_{1}$ hybrid CBA/Ca $\times$ C57BL/6 virgin female mice, 6-8 weeks old, were used as donors of embryos and were superovulated by an i.p. injection of 5 iu PMSG (Folligon: Intervet, Cambridge) between 12:00 and 13:00 h, followed $48 \mathrm{~h}$ later by 5 iu hCG (Chorulon: Intervet). The animals were then placed with $F_{1}$ males of the same cross and checked the following morning for the presence of a vaginal plug. Mating was assumed to occur at the mid-point of the dark period (18:00$06: 00 \mathrm{~h}$ ) and the morning on which the vaginal plug was found was designated as day 0.5 of gestation.

Decidua were recovered from the uteri of mated females between 10:00 and 11:00 $\mathrm{h}$ on days $6.5,7.5,8.5$ and 9.5 of gestation and placed in medium M2 (Quinn et al., 1982), which was used for the recovery and dissection of the conceptus. The 
decidua were opened as quickly as possible and the embryos and their membranes dissected free of the decidual mass and transferred to another Petri dish containing $2 \mathrm{ml}$ medium $\mathrm{M} 2$ for further processing.

\section{Dissection and incubation of samples}

After recovery from the decidual mass, conceptuses were dissected into their component parts using electrolytically sharpened tungsten needles. At day 6.5 and day 7.5 of gestation, Reichart's membrane was stripped back from the underlying egg cylinder, and the ectoplacental cone plus Reichart's membrane separated from the egg cylinder to provide two samples for comparison with whole undissected conceptuses. At day 8.5 of gestation, Reichart's membrane was reflected and the ectoplacental cone severed from the underlying yolk sac/allantois. The yolk sac/allantois was then dissected free from the embryo; in most cases it was not possible to differentiate between these two membranes. The pericardial sac was opened and the looped primitive heart tube severed anteriorly and posteriorly, and removed. The remaining visceral components, lying the length of the body below the developing somites, were dissected free and recovered. The remainder of the embryo was transected just posteriorly to the otic pit, to separate head from body; both of these were cut longitudinally to provide left and right sides for incubation in different media. In the case of the day 9.5 conceptus, the ectoplacental cone and yolk sac/allantois were separated from the embryo, the heart and visceral components recovered and the forelimb buds dissected free from the adjacent somites. The head was severed from the body at the otic pit and further divided into three sections by two transverse cuts to separate fore- and mid-brain regions and the hind brain with associated first brachial arch. Finally, the body was transected midway along its length to give anterior and posterior parts. Each of these was divided into two portions for incubation in different media.

After dissection, individual samples were washed by transfer through two changes of incubation medium using a drawn Pasteur pipette and transferred in a minimum volume of medium to the incubation droplets. The incubation medium was medium M2 modified to provide the desired concentration of glucose and lactate for a particular experiment. In all experiments, the incubation medium also contained $0.33 \mathrm{mmol}$ pyruvate $1^{-1}$ in addition to glucose and lactate. All incubations were carried out in droplets of medium in plastic Petri dishes under light paraffin oil (BDH, Poole, Dorset) at $37^{\circ} \mathrm{C}$, with one tissue sample per droplet; the volume of the droplets was chosen, following preliminary experiments, so that for the particular sample, approximately $50 \%$ of the glucose present in the droplet was utilized during the $2.5 \mathrm{~h}$ incubation period. This volume varied from $1 \mu \mathrm{l}$, for samples of day 6.5 ectoplacental cone, to $50 \mu \mathrm{l}$, for some of the samples recovered from the conceptus at day 9.5. For all experiments, control droplets containing no tissue sample were included in the dishes.

\section{Estimation of the metabolic turnover of glucose}

At the completion of the $2.5 \mathrm{~h}$ incubation, the tissue samples were recovered from the droplets and washed through two changes of protein-free phosphate-buffered saline. They were then transferred to Eppendorf tubes and any excess fluid was removed with a finely drawn Pasteur pipette, before storage at $-20^{\circ} \mathrm{C}$ for later assay of their protein content. After recovery of the tissue samples, the Petri dishes containing the incubation droplets were stored at $-20^{\circ} \mathrm{C}$ until measurement of the concentrations of both glucose and lactate.

For the protein assay, $200 \mu \mathrm{l}$ of phosphate buffer $(50 \mathrm{mmol}$ $1^{-1}, \mathrm{pH} 7.2$ ) containing $50 \mathrm{mmol} \mathrm{CHAPS}^{-1}$ (Sigma Chemical Co., St Louis, MO) was added to thawed tissue samples and the sample homogenized by sonication for 15-60 s, depending on the particular sample. Duplicate aliquots of the homogenized sample were assayed using Coomassie brilliant blue (Bradford, 1976). Glucose in the incubation medium was assayed using an ultramicrofluorescent technique (Leese and Barton, 1984; Gardner and Leese, 1986) carried out at nanolitre level. For incubations at day 6.5 , lactate was also measured by an ultramicrofluorescence technique (Gardner and Leese, 1990) but for the later stages of development, sufficient sample was available to allow assay of this metabolite using an automated analyser (Cobas Mira: Roche Diagnostic Systems, Welwyn City, Herts). The ultramicrofluorescence and automated (Mira) methods for lactate assay were cross-checked to ensure comparability of the results obtained. Glucose utilization and lactate accumulation were estimated as the differences between values for control droplets and incubated samples, and were expressed as nmol metabolite $1^{-1} \mu^{-1}$ protein over the incubation period. A preliminary experiment using conceptuses of day 7.5 incubated for $2.5 \mathrm{~h}$ and sampled at 50, 100 and $150 \mathrm{~min}$ after the commencement of incubation gave a linear regression of glucose utilization over time, and no significant deviation from linearity when the initial glucose concentration was either 5 or $1 \mathrm{mmol} \mathrm{l}^{-1}$, in a medium containing $1 \mathrm{mmol}$ lactate $1^{-1}$ plus $0.33 \mathrm{mmol}$ pyruvate $\mathrm{l}^{-1}$.

\section{Statistical analyses}

All data were transformed to logarithms, to equalize variances between groups, and subjected to analyses of variance by the method of unweighted means for disproportionate subclass numbers (Snedecor and Cochran, 1967). Orthogonal polynomials were used to isolate variances associated with specific comparisons and Duncan's multiple-range test was used for comparison of unrelated means.

\section{Results}

\section{Metabolism at day 6.5 and day 7.5 of pregnancy}

The turnover of glucose by conceptuses recovered at day 6.5 and day 7.5 of pregnancy was measured in three media: the first contained $1 \mathrm{mmol}$ (D) glucose $\mathrm{I}^{-1}, 1 \mathrm{mmol}$ (DL) lactate $\mathrm{l}^{-1}$, $0.33 \mathrm{mmol}$ pyruvate $\mathrm{I}^{-1}$; the second $5 \mathrm{mmol}$ (D) glucose $1^{-1}$, $1 \mathrm{mmol}(\mathrm{DL})$ lactate $\mathrm{l}^{-1}, 0.33 \mathrm{mmol}$ pyruvate $\mathrm{l}^{-1}$; and the third $1 \mathrm{mmol}$ (D) glucose $1^{-1}, 5 \mathrm{mmol}$ (DL) lactate $1^{-1}, 0.33 \mathrm{mmol}$ pyruvate $1^{-1}$. At each stage, bisected conceptuses were compared with whole undissected conceptuses. Only females carrying in excess of 11 implantation sites were used for these experiments. On any one occasion, the conceptuses from one 
Table 1. Glucose utilization and lactate accumulation by mouse conceptuses at day 6.5 and components at day 6.5 and day 7.5 of pregnancy

\begin{tabular}{|c|c|c|c|c|}
\hline \multicolumn{2}{|c|}{$\begin{array}{l}\text { Concentration of substrate } \\
\left(\text { mmol l} l^{-1}\right) \text { in medium }\end{array}$} & \multicolumn{3}{|c|}{ Metabolism of glucose by } \\
\hline Glucose & Lactate & Intact conceptus & $\mathrm{EPC}$ & Egg cylinder \\
\hline \multicolumn{5}{|c|}{ Day 6.5 of pregnancy } \\
\hline \multicolumn{5}{|c|}{ Glucose utilized } \\
\hline 1 & 1 & $1.06 \pm 0.16(7)$ & $0.93 \pm 0.24(4)$ & $1.16 \pm 0.32(4)$ \\
\hline 1 & 5 & $0.95 \pm 0.15(6)$ & $0.64 \pm 0.16(4)$ & $1.09 \pm 0.16(4)$ \\
\hline 5 & 1 & $1.95 \pm 0.38(6)$ & $1.70 \pm 0.58(4)$ & $1.77 \pm 0.32(4)$ \\
\hline \multicolumn{5}{|c|}{ Lactate accumulated } \\
\hline I & 1 & $2.03 \pm 0.32(7)$ & $1.97 \pm 0.39(4)$ & $2.30 \pm 0.61(4)$ \\
\hline I & 5 & $1.56 \pm 0.20(6)$ & $1.33 \pm 0.37(4)$ & $2.13 \pm 0.34$ \\
\hline 5 & 1 & $3.17 \pm 0.59(6)$ & $2.50 \pm 0.70$ & $3.47 \pm 0.94(4)$ \\
\hline \multicolumn{5}{|c|}{ Day 7.5 of pregnancy } \\
\hline \multicolumn{5}{|c|}{ Glucose utilized } \\
\hline 1 & 1 & $0.88 \pm 0.09$ & $0.86 \pm 0.07(4)$ & $1.27 \pm 0.18$ \\
\hline 1 & 5 & $0.78 \pm 0.03(4)$ & $0.84 \pm 0.06(4)$ & $1.34 \pm 0.11(4)$ \\
\hline 5 & 1 & $2.18 \pm 0.21(4)$ & $1.76 \pm 0.47(4)$ & $3.16 \pm 0.19(4)$ \\
\hline \multicolumn{5}{|c|}{ Lactate accumulated } \\
\hline 1 & 1 & $1.48 \pm 0.18(4)$ & $1.06 \pm 0.04(4)$ & $3.73 \pm 0.31(4)$ \\
\hline I & 5 & $1.12 \pm 0.11(4)$ & $1.06 \pm 0.09(4)$ & $1.52 \pm 0.19(4)$ \\
\hline 5 & I & $1.94 \pm 0.14(6)$ & $1.93 \pm 0.23$ & $5.02 \pm 0.73$ \\
\hline
\end{tabular}

Values are means \pm SEM (number of observations) and are expressed as $\mathrm{nmol} \mu \mathrm{g}^{-1}$ protein over the $2.5 \mathrm{~h}$ incubation. All media contained pyruvate $\left(0.33 \mathrm{mmol} \mathrm{I}^{-1}\right)$ in addition to glucose and lactate. EPC: ectoplacental cone.

female were collected and for each medium used, two conceptuses were dissected and their parts added to individual droplets of medium. The remaining undissected conceptuses from the litter were distributed among droplets of each medium. For both periods of gestation, the experiment was repeated on two separate occasions so that variation between siblings could be compared with that between litters.

The data for these trials are presented in Table 1. Statistical analysis of these data showed that the utilization of glucose by the conceptus at day 7.5 was not significantly different from that by the conceptus on day 6.5 . However, at both stages, its utilization by the ectoplacental cone was less than that by the egg cylinder $(P<0.05)$. A change in the concentration of lactate in the medium had no significant effect on the metabolism of $1 \mathrm{mmol}$ glucose $1^{-1}$, but an increase in glucose concentration from 1 to $5 \mathrm{mmol} 1^{-1}$ led to a substantial and significant increase in glucose turnover of the order of $100 \%$. A significant difference $(P<0.05)$ between the average value for the two litters, compared with the differences between littermates, was found for conceptuses recovered on day 6.5, but not day 7.5 of pregnancy.

At day 6.5, glycolysis appeared to be the major route of glucose metabolism with almost quantitative conversion of glucose to lactate. By day 7.5, the proportion of glucose utilized that could be accounted for as lactate had fallen to an average of $71 \%$. Statistical analysis of the data for percentage glucose converted to lactate showed a highly significant difference between days in this conversion but no significant effect of substrate concentration or origin of sample.

\section{Metabolism at day 8.5 of pregnancy}

Two experiments were undertaken to measure the metabolism of glucose by conceptuses recovered at day 8.5 of pregnancy. All media contained $1 \mathrm{mmol}$ (DL) lactate $1^{-1}$ plus $0.33 \mathrm{mmol}$ pyruvate $\mathrm{I}^{-1}$ in addition to glucose. At day 8.5 , the conceptus undergoes axial rotation to achieve the fetal position. One litter of pups was recovered just before this rotation, and glucose metabolism by the ectoplacental cone, yolk sac and embryo recovered from these conceptuses, incubated in the

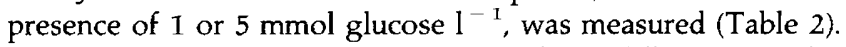
Statistical analysis revealed highly significant differences in the amount of glucose utilized and lactate accumulated between the ectoplacental cone and yolk sac $(P<0.01)$. The metabolism of glucose by the embryo lay midway between the values for the extraembryonic membranes. As with conceptuses at earlier stages, increasing the concentration of glucose from $I$ to $5 \mathrm{mmol} \mathrm{I}^{-1}$ approximately doubled glucose utilization. For these samples, the proportion of glucose recovered as lactate varied between 60 and $75 \%$ (average $66 \%$ ).

Data for the metabolism of glucose by the conceptus at day 8.5 after axial rotation are presented (Table 3). For this experiment, two conceptuses from each of two litters were dissected to recover the ectoplacental cone, yolk sac and embryo. The embryonic components were further dissected to provide samples for incubation in medium containing either 1 or $5 \mathrm{mmol}$ glucose $\mathrm{l}^{-1}$. The heart was removed from the embryo for incubation in the medium containing $5 \mathrm{mmol}$ glucose $1^{-1}$. The remainder of the embryo was dissected and 
Table 2. Glucose metabolism by components of conceptuses recovered on day 8.5 of gestation, but before axial rotation, and incubated in the presence of $1 \mathrm{mmol}$ or $5 \mathrm{mmol}$ glucose $\mathrm{I}^{-1}$

\begin{tabular}{|c|c|c|c|c|}
\hline \multirow[b]{2}{*}{$\begin{array}{l}\text { Tissue sample } \\
\text { incubated }\end{array}$} & \multicolumn{2}{|c|}{ Glucose utilized } & \multicolumn{2}{|c|}{ Lactate accumulated } \\
\hline & $\begin{array}{c}1 \mathrm{mmol} \\
{\text { glucose } 1^{-1}}^{-1}\end{array}$ & $\begin{array}{c}5 \mathrm{mmol}^{-} \\
{\text {glucose } \mathrm{I}^{-1}}^{-1}\end{array}$ & $\begin{array}{c}1 \mathrm{mmol} \\
\text { glucose } \mathrm{l}^{-1}\end{array}$ & $\begin{array}{l}5 \mathrm{mmol} \\
\text { glucose } \mathrm{l}^{-1}\end{array}$ \\
\hline EPC & $0.51 \pm 0.12$ & $1.08 \pm 0.09$ & $0.62 \pm 0.22$ & $1.29 \pm 0.11$ \\
\hline Yolk sac & $1.55 \pm 0.33$ & $2.50 \pm 0.11$ & $2.34 \pm 0.07$ & $3.32 \pm 0.45$ \\
\hline Embryo & $1.23 \pm 0.22$ & $1.71 \pm 0.08$ & $1.77 \pm 0.05$ & $2.22 \pm 0.32$ \\
\hline
\end{tabular}

Values are expressed as nmol $\mu \mathrm{g}^{-1}$ protein over the $2.5 \mathrm{~h}$ incubation period and are means \pm sem for observations on four littermates at each concentration of glucose. All media contained $1 \mathrm{mmol}$ lactate $\mathrm{I}^{-1}+0.33 \mathrm{mmol}$ pyruvate $\mathrm{l}^{-1}$ in addition to glucose. EPC: ectoplacental cone.

Table 3. Glucose utilization and lactate accumulation by components of the conceptuses at day 8.5 recovered after completion of axial rotation and incubated in the presence of 1 mmol or $5 \mathrm{mmol}$ glucose $1^{-1}$

\begin{tabular}{|c|c|c|c|c|}
\hline \multirow[b]{2}{*}{$\begin{array}{l}\text { Tissue } \\
\text { component }\end{array}$} & \multicolumn{2}{|c|}{ Glucose utilized } & \multicolumn{2}{|c|}{ Lactate accumulated } \\
\hline & $\begin{array}{c}1 \mathrm{mmol} \\
{\text { glucose } 1^{-1}}^{-1}\end{array}$ & $\begin{array}{c}5 \mathrm{mmol} \\
\text { glucose } 1^{-1}\end{array}$ & $\begin{array}{c}1 \mathrm{mmol} \\
{\text { glucose } \mathrm{l}^{-1}}\end{array}$ & $\begin{array}{c}5 \mathrm{mmol} \\
\text { glucose } 1^{-1}\end{array}$ \\
\hline EPC & $0.56 \pm 0.11^{\mathrm{a}}$ & $1.21 \pm 0.37^{\mathrm{a}}$ & $0.91 \pm 0.13^{a}$ & $1.47 \pm 0.26^{\mathrm{a}}$ \\
\hline Yolk sac & $1.67 \pm 0.20^{b}$ & $2.62 \pm 0.56^{b}$ & $3.09 \pm 0.53^{\mathrm{bc}}$ & $3.85 \pm 0.45^{\mathrm{b}}$ \\
\hline \multicolumn{5}{|l|}{ Embryo } \\
\hline Head & $1.78 \pm 0.21^{b}$ & $2.85 \pm 0.6 \mathrm{I}^{\mathrm{b}}$ & $3.20 \pm 0.45^{\mathrm{c}}$ & $4.30 \pm 0.64^{b}$ \\
\hline Body & $1.36 \pm 0.20^{\mathrm{b}}$ & $2.29 \pm 0.49^{b}$ & $2.42 \pm 0.56^{b c}$ & $4.04 \pm 0.79^{b}$ \\
\hline Viscera & $1.15 \pm 0.26^{\mathrm{b}}$ & $2.77 \pm 0.60^{b}$ & $1.75 \pm 0.22^{6}$ & $4.00 \pm 1.03^{b}$ \\
\hline Heart & - & $3.28 \pm 1.22^{b}$ & - & $5.31 \pm 2.23^{\mathrm{b}}$ \\
\hline
\end{tabular}

Values are expressed as $\mathrm{nmol} \mu \mathrm{g}^{-1}$ protein per $2.5 \mathrm{~h}$ and are the means \pm SEM for four observations. All media contained 1 mmol lactate $1^{-1}+0.33 \mathrm{mmol}$ pyruvate $\mathrm{l}^{-1}$ in addition to glucose. EPC: ectoplacental cone.

Within each column, pairs of values with no superscript letters in common were significantly different from each other $(P<0.05)$.

half of each component was incubated in the presence of either 1 or $5 \mathrm{mmol}$ glucose $\mathrm{I}^{-1}$.

Statistical analysis of the data showed that, as in the samples collected at days 6.5 and 7.5 of pregnancy, there was a highly significant response to increasing glucose concentration $(P<0.01)$ which was consistent across all samples tested, with no significant interaction between glucose concentration and tissue sample. For extraembryonic tissue, the ectoplacental cone was much less active than the yolk sac $(P<0.01)$ which, in turn, exhibited a similar rate of glucose utilization to the embryonic tissues tested. No significant differences were found between the embryonic tissues in their turnover of glucose. Statistical analysis of the data for lactate accumulation gave similar results to those described above except that in this case, there was some indication that the tissue from the head was more metabolically active than visceral tissue. At this stage, lactate accumulation accounted, on average, for $81 \%$ of glucose utilized. At $1 \mathrm{mmol}$ glucose $\mathrm{l}^{-1}$, lactate accounted for $89 \%$ of glucose turnover but only $79 \%$ at $5 \mathrm{mmol}$ glucose $1^{-1}$; this difference was not significant.

In a separate, small trial, glucose metabolism by conceptuses at day 8.5 was repeated using a medium in which the lactate concentration was raised from 1 to $5 \mathrm{mmol} \mathrm{l}^{-1}$. The results of this limited experiment were similar to those obtained with 1 mmol lactate $\mathrm{l}^{-1}$.

\section{Metabolism at day 9.5 of pregnancy}

This final experiment was designed to study the metabolism of glucose by the components of conceptuses at day 9.5. Two conceptuses from each of two litters were dissected for incubation in media containing either 1 or $5 \mathrm{mmol}$ glucose $1^{-1}$. Both media also contained $1 \mathrm{mmol}$ lactate $l^{-1}$ plus $0.33 \mathrm{mmol}$ pyruvate $1^{-1}$. Samples of ectoplacental cone, yolk sac, foreand hind-body were incubated in 1 mmol glucose $1^{-1}$. Samples of these tissues plus the head components, viscera, heart and fore limb buds were incubated in $5 \mathrm{mmol}$ glucose $\mathrm{l}^{-1}$ (Table 4).

As in the other experiments, glucose concentration had a highly significant effect on its utilization by the tissues. However, in this case, there was a significant interaction between the effects of glucose concentration and the origin of the sample. For the yolk sac and body parts, an increase in glucose concentration caused a 2-2.5-fold increase in its utilization, as seen for all tissues at the earlier stages tested. For the ectoplacental cone at this stage, the increase in glucose 
Table 4. Metabolism of glucose by components of conceptuses recovered on day 9.5 of gestation and incubated in media containing either $1 \mathrm{mmol}$ or $5 \mathrm{mmol}$ glucose $\mathrm{l}^{-1}$

\begin{tabular}{|c|c|c|c|c|}
\hline \multirow[b]{2}{*}{$\begin{array}{l}\text { Tissue sample } \\
\text { incubated }\end{array}$} & \multicolumn{2}{|c|}{ Glucose utilized } & \multicolumn{2}{|c|}{ Lactate accumulated } \\
\hline & $\begin{array}{c}1 \mathrm{mmol} \\
\text { glucose } \mathrm{l}^{-1}\end{array}$ & $\begin{array}{c}5 \mathrm{mmol} \\
\text { glucose } 1^{-1}\end{array}$ & $\begin{array}{c}1 \mathrm{mmol} \\
\text { glucose } \mathrm{l}^{-\mathrm{I}}\end{array}$ & $\begin{array}{l}5 \mathrm{mmol} \\
\text { glucose } 1^{-1}\end{array}$ \\
\hline EPC & $0.21 \pm 0.03^{\mathrm{a}}$ & $0.93 \pm 0.14^{\mathrm{a}}$ & $0.46 \pm 0.07^{\mathrm{a}}$ & $1.67 \pm 0.28^{\mathrm{a}}$ \\
\hline Yolk sac & $0.98 \pm 0.04^{\mathrm{b}}$ & $2.68 \pm 0.09^{b}$ & $1.79 \pm 0.07^{b}$ & $4.09 \pm 0.12^{b}$ \\
\hline \multicolumn{5}{|l|}{ Embryo: } \\
\hline Head - fore & - & $1.51 \pm 0.06^{\mathrm{c}}$ & - & $2.07 \pm 0.16^{\mathrm{ac}}$ \\
\hline- mid & - & $1.57 \pm 0.13^{c}$ & - & $2.36 \pm 0.19^{a c}$ \\
\hline- hind & - & $1.44 \pm 0.10^{c}$ & - & $2.15 \pm 0.23^{\mathrm{ac}}$ \\
\hline Body - fore & $0.55 \pm 0.06^{c}$ & $1.39 \pm 0.13^{c}$ & $0.77 \pm 0.13^{c}$ & $1.89 \pm 0.30^{\mathrm{ac}}$ \\
\hline- hind & $0.64 \pm 0.09^{c}$ & $1.32 \pm 0.11^{a c}$ & $1.01 \pm 0.18^{c}$ & $1.77 \pm 0.21^{a c}$ \\
\hline Limb buds & - & $1.28 \pm 0.11^{\mathrm{ac}}$ & - & $1.72 \pm 0.13^{\mathrm{ac}}$ \\
\hline Viscera & - & $1.80 \pm 0.07^{b c}$ & - & $2.41 \pm 0.40^{\mathrm{ac}}$ \\
\hline Heart & - & $1.77 \pm 0.28^{c}$ & - & $2.27 \pm 0.24^{\mathrm{ac}}$ \\
\hline
\end{tabular}

Values are expressed as $\mathrm{nmol} \mu \mathrm{g}^{-1}$ protein per $2.5 \mathrm{~h}$ and are the means \pm SEM for four observations. All media contained $1 \mathrm{mmol}$ lactate $\mathrm{l}^{-1}+0.33 \mathrm{mmol}$ pyruvate $\mathrm{I}^{-1}$ in addition to glucose. EPC: ectoplacental cone.

Within each column, values with no superscript letters in common were significantly different from each other $(P<0.05)$.

metabolism in response to an increase in concentration was approximately fourfold. Among the samples recovered, the ectoplacental cone had the lowest rate of turnover of glucose and the yolk sac the highest. Duncan's multiple-range test failed to demonstrate clear, significant differences among the tissues of the embryo. Nevertheless, by the use of polynomial coefficients to test specific comparisons, it could be shown that the average utilization of glucose by the head components, although higher, was not significantly above that by the body and limb bud samples $(0.1>P>0.05)$ but that the last mentioned tissues differed significantly $(P<0.01)$ from the visceral components (viscera and heart). For lactate accumulation from glucose, the comparisons among tissues using polynomial coefficients were even more clear cut, and accumulation by head components was significantly higher than that by body components $(P<0.01)$, which in turn were significantly different from the visceral components $(P<0.01)$. A limited experiment at this stage using media containing $5 \mathrm{mmol}^{\text {lactate } \mathrm{I}^{-1}}$ rather than $1 \mathrm{mmol}$ lactate $\mathrm{l}^{-1}$ provided similar results to those obtained above.

On average $77 \%$ of glucose utilized by the conceptus at day 9.5 appeared as lactate. However, at this time, a significantly greater proportion of glucose was converted to lacate $(P<0.01)$ in the presence of $1 \mathrm{mmol}$ glucose $\mathrm{l}^{-1}(88 \%)$ than in the presence of $5 \mathrm{mmol}$ glucose $\mathrm{l}^{-1}(72 \%)$. In addition, the ectoplacental cone converted more glucose to lactate than did the yolk sac, which in turn converted more glucose to lactate than the body parts.

\section{Analysis of changes in metabolism during development}

The data from all the above experiments were further analysed in an attempt to establish trends in metabolism as development progressed. The ectoplacental cone was the only tissue that could be characterized and incubated separately at all the stages of pregnancy studied. All data available for this

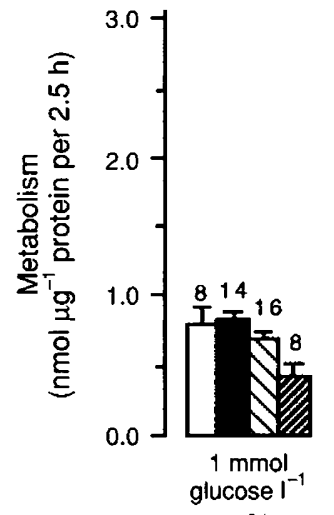

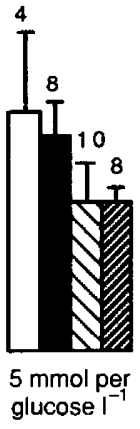

Glucose utilized

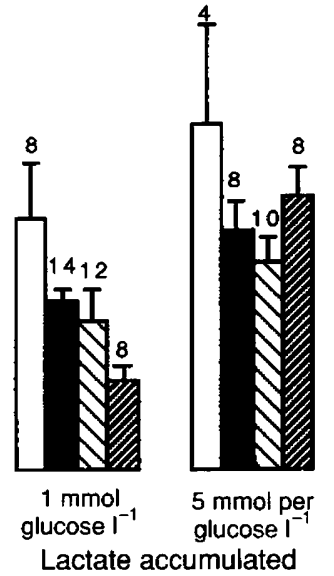

Fig. 1. Changes in glucose utilization and lactate production by the ectoplacental cone during development from day 6.5 to day 9.5 of pregnancy. Values are means with SEM for the number of observations shown above the columns. $(\square)$ : day $6.5 ;(\mathbb{\square})$ day $7.5 ;(\square)$ : day 8.5 ; (వ): day 9.5.

structure at each of the 4 days studied were analysed after logarithmic transformation to determine the statistical significance of changes over time. This analysis showed that, in addition to a consistent increase in glucose turnover in response to raising the glucose concentration to $5 \mathrm{mmol} \mathrm{I}^{-1}$ in the medium, there was a significant linear decrease in its turnover as pregnancy advanced $(P<0.01)$, with no significant deviations from linearity in the analysis. At day 9.5 of pregnancy, the rate of disappearance of glucose and appearance of lactate was, on average, only $60 \%$ of the rate found at day 6.5. The time trends of these data are illustrated (Fig. 1).

For embryos at day 8.5 and day 9.5 , it was possible to compare the metabolism of the head, body and visceral components to estimate time trends. All results, including those from experiments in the presence of $5 \mathrm{mmol}_{\text {lactate } \mathrm{I}^{-1}}$ as well 

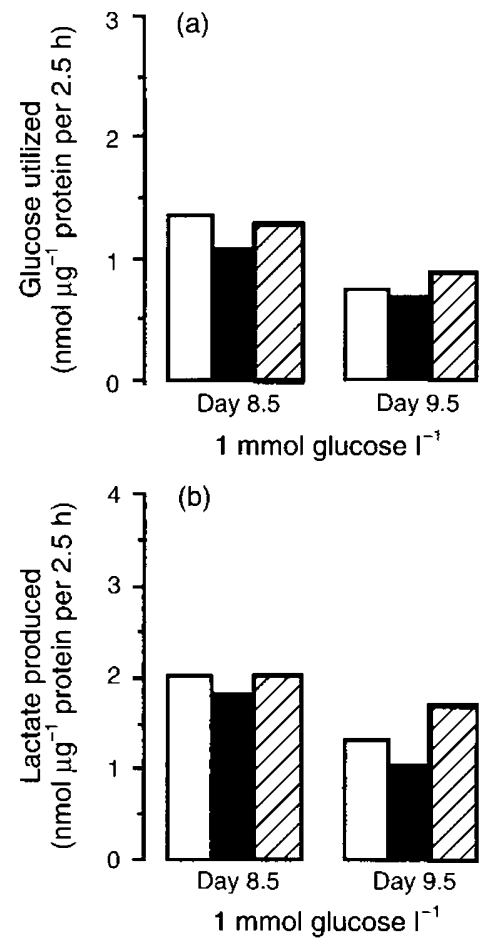

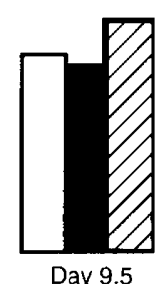

$5 \mathrm{mmol}$ glucose $\mathrm{I}^{-1}$

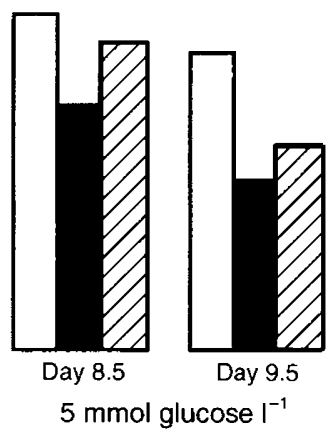

Fig. 2. Glucose utilization (a) and lactate production (b) by the head

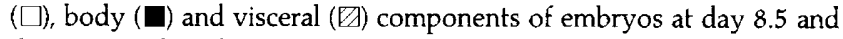
day 9.5 incubated in medium containing either 1 or $5 \mathrm{mmol}$ glucose $1^{-1}$. Values are the antilogarithms of the means of the $\log$ transformed data.

as 1 mmol lactate $\mathrm{l}^{-1}$, were used to provide sufficient data to test this time effect. Statistical analysis after logarithmic transformation revealed a highly significant difference between days in both glucose utilization and lactate formation $(P<0.01)$ with a $25 \%$ fall in metabolism between day 8.5 and day 9.5 of pregnancy. There was a highly significant effect of glucose concentration on glucose turnover, and the metabolism of body tissue was consistently about $20 \%$ lower $(P<0.05$ for glucose utilization, $P<0.01$ for lactate accumulation) than that of the head or viscera (Fig. 2). In the case of the yolk sac, there was no clear-cut evidence of a decrease with time between day 8.5 and day 9.5 of pregnancy.

Finally, the turnover of glucose per hour for the whole conceptus was estimated from the data for rates of glucose utilization by the component parts weighted for their relative contributions to the whole conceptus, based on their protein contents. Although the turnover of glucose tended to increase exponentially as development progressed, the normal exponential growth curve did not fit the data adequately as there were small but significant deviations from linearity when the logarithm of glucose turnover was plotted against time (Fig. 3). Analysis of these plots revealed a significant curvilinear asymptotic regression with no deviation from parallelism for the curves at $1 \mathrm{mmol}$ and $5 \mathrm{mmol}$ glucose $1^{-1}$. This asymptotic regression for the whole conceptus is consistent with the finding of a reducing rate of metabolism of glucose by its constituent parts as development progresses. The mean regression equation of log glucose utilization $(y)$ against age of the conceptus in hours after coitus $(x)$ was:

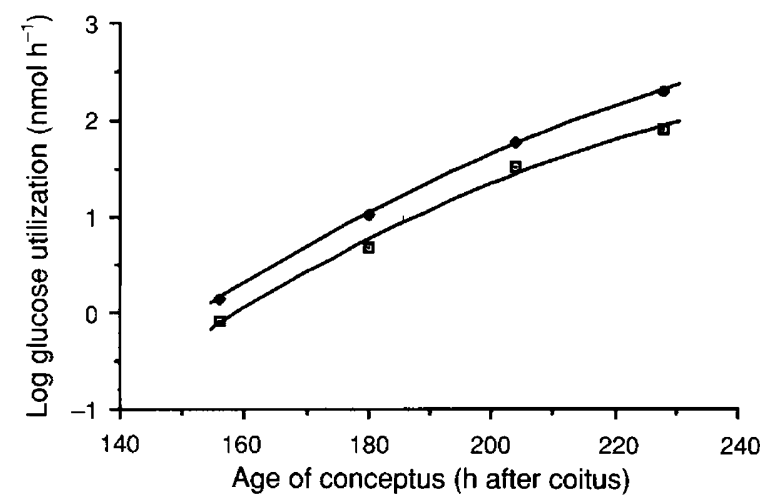

Fig. 3. Plots of the logarithm of the total turnover of glucose by the mouse conceptus against developmental age and the lines of best fit for the second order polynominal regressions derived from incubations in medium containing either $I(\bullet)$ or $5(\bullet)$ mmol glucose $\mathrm{l}^{-1}$.

$$
y=-9.64+0.0838 x-0.000141 x^{2}
$$

An estimate of the relative rate of increase in metabolism with time can be made from the differential of this equation. On day 6.5 of pregnancy, this was calculated to be $0.092 \mathrm{nmol}$ $\mathrm{h}^{-1} \mathrm{nmol}^{-1}$ glucose utilized. By day 9.5, this had fallen progressively to $0.046 \mathrm{nmol} \mathrm{h}^{-1} \mathrm{nmol}^{-1}$ utilized.

\section{Discussion}

Between day 6.5 and day 9.5 of pregnancy, the conceptus undergoes extensive growth and completes a major part of its differentiation. As pregnancy advances, the demands of growth call for the generation of increasing amounts of metabolic energy from the catabolism of exogenous substrates. During the preimplantation period of development, these substrates are absorbed directly from uterine luminal secretion, which is known to contain glucose, lactate and pyruvate (Wales and Edirisinghe, 1989). As the mouse conceptus develops within the decidua and establishes its placenta, it is likely to be exposed to a changing nutritional environment. Rates of diffusion of glucose from maternal vessels to the tissues of the conceptus, as well as the proportion converted by decidual cells to metabolites such as lactate, may vary from time to time. Thus, the absolute amount and relative proportion of different substrates in the immediate environment of the embryo may change. In the present experiments, the metabolism of glucose by the post-implantation conceptus was studied using a number of substrate combinations, in an attempt to cover some of the possible outcomes in vivo.

At all stages of development studied, the conceptus could utilize glucose as an energy source for its requirements. The finding that glycolysis was the major pathway for the utilization of glucose immediately after implantation, but that dependence on this pathway decreased as development progressed, confirms the observations of Clough and Whittingham (1983). This fall in dependence on glycolysis to supply metabolic energy from glucose during postimplantation development may be a phenomenon common to rodent conceptuses. In rats, initial energy-yielding metabolism is dominated by glycolysis but oxidative pathways become more prominent as 
development progresses (Tanimura and Shepard, 1970; Cox and Gunsberg, 1972a, b; New, 1978). However, this relationship does not necessarily hold for all mammalian conceptuses. In sheep conceptuses, for example, the opposite appears to be the case, with glycolysis increasing at the expense of glucose oxidation during initial embryogenesis (Du and Wales, 1993).

In the present experiments, a doubling in glucose utilization resulted from a fivefold increase in its concentration, suggesting that the mechanisms for glucose transport or metabolism were approaching saturation at the higher level. Similar trends have been recorded for the utilization of glucose by preimplantation mouse embryos (Brinster, 1967; Wales, 1986). The question as to whether saturation had been reached was not pursued here, as concentrations of glucose in excess of $5 \mathrm{mmol}$ $1^{-1}$ are unlikely to be experienced by the embryo in vivo. Some evidence that the utilization of glucose had reached a plateau when its concentration reached $5 \mathrm{mmol} \mathrm{1}^{-1}$ comes from Clough and Whittingham (1983), who reported no significant increase in glucose oxidation by mouse conceptuses at day 7.5 when glucose is raised from 5.56 to $22 \mathrm{mmol} \mathrm{I}^{-1}$ in the medium.

Although the present experiments were unable to demonstrate an effect of raising the lactate concentration from 1 to $5 \mathrm{mmol} 1^{-1}$ on glucose utilization, high concentrations of lactate $\left(25 \mathrm{mmol} \mathrm{l}^{-1}\right)$ depress glucose oxidation by the conceptuses at day 7.5 (Clough and Whittingham, 1983). This latter result is not unexpected, as lactate at a high concentration should compete effectively with the products of glycolysis for entry into the TCA cycle. In the present experiments, total glucose utilization was measured and, as glycolysis makes up the majority $(70-90 \%)$ of its turnover, any possible effects of lower concentrations of lactate on glucose oxidation would be masked by glycolytic turnover, which appears to be unaffected, at least by modest increases in lactate.

During the initial differentiation of developing preimplantation embryos into trophectoderm and inner cell mass, there is evidence of a metabolic as well as a morphogenic differentiation in the two committed cell lines; the trophectoderm demonstrates a lower utilization of glucose than does the inner cell mass (Hewitson and Leese, 1993). This difference is perpetuated after differentiation, and the turnover of glucose by the ectoplacental cone, derived from the trophectoderm, remains low compared with that of other components. At the later stages of organogenesis, progressive growth and differentiation provide the opportunity to examine the metabolism of a range of tissues in the conceptus. At day 8.5, glucose turnover of the yolk sac was equivalent to that of the embryonic tissues and little metabolic differentiation between the developing embryonic tissues was evident. By day 9.5, the yolk sac outstrips the metabolism of the embryo by a factor of about two. This may reflect the nutritional role of this membrane. There is also evidence that the tissues of the embryo are undergoing some metabolic differentiation, with the metabolism of the body falling behind that of the head and visceral components.

In addition to this changing pattern of glucose metabolism between tissues as development progressed, there was a general trend towards a progressive slowing in the rate of metabolism, a change that may result from a reduction in glucose uptake consequent to a fall in the expression of glucose transporters in the tissues (Smith and Gridley, 1992). Similar findings have been shown in mice (Clough and Whittingham, 1983) and rats (Ellington, 1987). In sheep, the extraembryonic membranes in particular undergo a remarkable reduction in glucose turnover as development progresses from day 13 to day 19 of pregnancy (Du and Wales, 1993; Wales and Waugh, 1993). This period of pregnancy in sheep covers approximately the same embryological time scale as that studied in the rodent experiments, and the sheep data also produce asymptotic regressions as found for the present data.

If the present data for mouse conceptuses are converted to the $Q$ notation on a dry mass basis, they can be compared with figures for the utilization of glucose by slices of adult tissue (Long, 1971). These calculated values of $\mathrm{Q}_{\mathrm{G}} \mathrm{O}_{2}$ for mouse embryonic tissues $(60-70$ for the embryos and yolk sac; $30-60$ for the ectoplacental cone) are much higher than the figures for adult rodent tissue incubated in media with glucose as the sole substrate (2-10 for most tissues). This finding suggests that the progressive fall in glucose utilization seen over the early period of organogenesis must continue throughout subsequent development to reach the low values recorded in the adult.

No other data are available for glucose turnover by dissected embryonic tissues in rodent species for direct comparison with the present estimates. However, measurements of glucose utilization by rat conceptuses with intact yolk sacs cultured in serum (Tanimura and Shepard, 1970; Robkin and Cockroft, 1978) provide some opportunity for comparisons to be made. These experiments indicate that glucose turnover by rat embryos at day 10.5 to day 11.5 of pregnancy, which is approximately the embryological equivalent of day 8.5 to day 9.5 in mice, is of the same order as found in the present study $\left(2-3 \mathrm{nmol} \mu \mathrm{g}^{-1}\right.$ protein per $\left.2.5 \mathrm{~h}\right)$. The only other data for mice at this stage also comes from studies with whole embryos (Clough and Whittingham, 1983). These authors estimate glucose turnover at about double that found in the present experiments. This difference may be more apparent than real and may result from the very different methods of estimating protein in each study. If the earlier figures for catabolic turnover per embryo are converted to turnover $\mu \mathrm{g}^{-1}$ protein using the present estimates of protein content, their values are similar to those found here.

Although the estimates of glucose turnover by embryos of different rodents appear to be similar, the estimates for sheep conceptuses during initial embryogenesis are much lower (0.1-0.3 nmol $\mu \mathrm{g}$ protein $^{-1}$ per $2.5 \mathrm{~h}$ ). Over this period of embryogenesis, the sheep conceptus is making only tentative contact with the endometrium through the cotyledons and therefore must rely heavily on the absorption of substrate from histotroph for its nourishment. This appears to be reflected in the enormous development of extraembryonic membranes with low metabolic turnover. By contrast, mouse conceptuses rely much more on haemotroph after early implantation and this should result in fewer constraints on substrate availability. The evolutionary response to this appears to have been the development of relatively compact membranes with high metabolic turnover and progressive changes in the utilization of glucose by both membranes and embryo during the development of the placenta.

Clearly, our results aid in the understanding of the biochemical events associated with early development, especially at the 
crucial time when the embryo is adapting to changes in its environment. At this time, the conceptus is vulnerable to influences that may lead to early embryonic mortality. The present information may lay some of the foundations for understanding the biochemical basis of this vulnerability.

The authors thank the University of York for the provision of funds to cover laboratory expenses associated with this project. R. G. Wales is also indebted to Murdoch University for support of an Outside Studies Programme to undertake this work.

\section{References}

Bradford MM (1976) A rapid and sensitive method for the quantitation of microgram quantities of protein utilising the principle of protein-dye binding Analytical Biochemistry 85 248-254

Brinster RL (1967) Carbon dioxide production from glucose by the preimplantation mouse embryo Experimental Cell Research 47 271-277

Clough JR and Whittingham DG (1983) Metabolism of $\left[{ }^{14} \mathrm{Clglucose}\right.$ by postimplantation mouse embryos in vitro Journal of Embryology and Experimental Morphology 74 133-142

Cockroft DL (1979) Nutrient requirements of rat embryos undergoing organogenesis in vitro Journal of Reproduction and Fertility 57 505-510

Cox SJ and Gunberg DL (1972a) Metabolic utilization by isolated embryonic hearts in vitro Journal of Embryology and Experimental Morphology 28 235-245

Cox SJ and Gunberg DL (1972b) Energy metabolism in isolated rat embryo hearts: effect of metabolic inhibitors Joumal of Embryology and Experimental Morphology 28 591-599

Du ZF and Wales RG (1993) Glycolysis and glucose oxidation by the sheep conceptus at different oxygen concentrations Reproduction, Fertility and Development 5 383-393

Ellington SKL (1987) In vitro analysis of glucose metabolism and embryonic growth in postimplantation rat embryos Development 100 431-439

Gardner DK and Leese HJ (1986) Non-invasive measurement of nutrient uptake by single cultured preimplantation mouse embryos Human Reproduction 1 25-27

Gardner DK and Leese HJ (1990) Concentrations of nutrients in mouse oviduct fluid and their effects on embryo development and metabolism in vitro Joumal of Reproduction and Fertility 88 361-336
Gunberg DL (1976) In vitro development of postimplantation rat embryos cultured on dialysed rat serum Teratology 14 65-70

Hewitson LC and Leese HJ (1993) Energy metabolism of the trophectoderm and inner cell mass of the mouse blastocyst Journal of Experimental Zoology 267 $337-343$

Leese HJ and Barton AM (1984) Pyruvate and glucose uptake by mouse ova and preimplantation embryos Journal of Reproduction and Fertility 32 9-13

Long C (Ed) (1971) Biochemists' Handbook E \& FN Spon Ltd, London

New DAT (1978) Whole-embryo culture and the study of mammalian embryos during organogenesis Biological Reviews 53 81-122

Papaconstantinou J (1967) Metabolic control of growth and differentiation in vertebrate embryos. In The Biochemistry of Animal Development pp 57-113 Ed. R Weber. Academic Press, New York and London

Quinn J, Barros C and Whittingham DG (1982) Preservation of hamster oocytes to assay the fertilizing capacity of human spermatozoa Journal of Reproduction and Fertility 66 161-168

Robkin MA and Cockroft DL (1978) The effect of carbon monoxide on glucose metabolism and growth of rat embryos Theriogenology 18 337-342

Shepard TH, Tanimura T and Robkin MA (1970) Energy metabolism in early mammalian embryos Developmental Biology Supplement 4 42-5

Smith DD and Gridley T (1992) Differential screening of a PCR-generated mouse cDNA library; glucose transporters are differentially expressed in postimplantation mouse embryos Development $116555-561$

Snedecor GW and Cochran WG (1967) Statistical Methods (6th Edn). Iowa State University Press, Ames

Spratt NT, Jr (1958) Chemical control of development. In The Chemical Basis of Development pp 629-645 Eds WD McElroy and B Glass. John Hopkins Press, Baltimore

Tanimura T and Shepard TH (1970) Glucose metabolism by rat embryos in vitro Proceedings of the Society of Experimental Biology and Medicine 135 $51-55$

Wales RG (1986) Measurement of glucose turnover in single mouse embryos Journal of Reproduction and Fertility 76 717-725

Wales RG and Edirisinghe WR (1989) Volume of fluid and concentration of cations and energy substrates in the uteri of mice during early pseudopregnancy Reproduction, Fertility and Development 1 171-178

Wales RG and Waugh EE (1993) Catabolic utilization of glucose by the sheep conceptus between days 13 and 19 of pregnancy Reproduction, Fertility and Development 5 111-122 